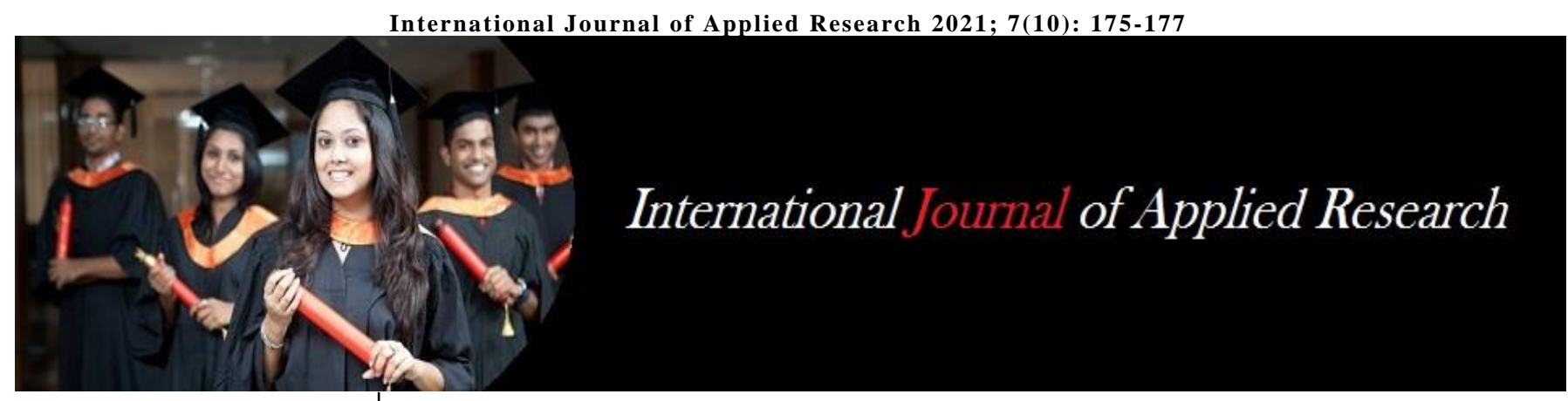

ISSN Print: $2394-7500$

ISSN Online: 2394-5869

Impact Factor: 8.4

IJAR 2021; 7(10): 175-177

www.allresearchjournal.com

Received: 28-08-2021

Accepted: 30-09-2021

Arunim Kumar Srivastava

Fashion Designer \& Educator,

New Delhi, India
Corresponding Author:

Arunim Kumar Srivastava

Fashion Designer \& Educator,

New Delhi, India

\section{Sohrai the tribal art}

\section{Arunim Kumar Srivastava}

DOI: https://doi.org/10.22271/allresearch.2021.v7.i10c.9037

\section{Abstract}

Women are the mainstays of our general public; the pioneers of customary painting workmanship rehearse in rustic India. Warli art, Gond craftsmanship, and Madhubani canvases are instances of their fine arts. this undertaking shows the abilities and endeavors of the tribal women which has a place with Jharkhand the place where there is minerals. The women of Ganju and Kurmi villages that, adorn their mud houses during these events with visual lines and themes. the ladies' specialists to explore these paintings. The Indian people expressions with painting assume significant part in making new plans. This undertaking intends to safeguard the creativity of the artistic expression.

Keywords: Sohrai \& Kohbar art, mural technique, originality

\section{Introduction}

Jharkhand is an essential for the focal ancestral belt of India and home to in excess of 40 Adivasi people group like Munda, Oraon, Ho, Santal, Birhor and Kharia. The homes of these networks commonly involve mud houses situated inside paddy fields and woodlands. Driving along the thruway and transforming into one of the more modest streets, one is probably going to discover groups of flawlessly put and painted mud houses flanking the road. In the months among October and January especially, the houses are brilliant, having been newly painted by the town ladies in anticipation of the reap celebration of Sohrai. This is considered as a favorable time, when the work of art of the house's frames part of the custom recharging of the residence and imprints the finish of one horticultural cycle and the start of another. The artistic creation of paintings on the event of Sohrai has prompted its terminology as Sohrai workmanship. It is additionally a not unexpected practice for ladies among some country networks to paint wall paintings in anticipation of weddings. Such canvases are known as Khovar, where kho alludes to give in or asylum and var alludes to the marriage couple. The word in this way alludes to the wall painting specialty of the wedding room. Both Sohrai and Khovar anyway are not solitary customs but rather expansive terms including a scope of wall painting practices and plans normal for Jharkhand. This article centers around two areas, Hazaribagh in the north and Singhbhum in the south, and talks about the creation, plan and themes, and the meaning of the wall painting workmanship in each site. comprehend the job of wall paintings in the conservation of mud engineering. Mud is one of the most seasoned structure materials and is widely utilized by networks all throughout the planet. In spite of prevalent thinking, mud structures can be incredibly solid designs that keep going for quite a long time. This anyway requires customary upkeep through putting and painting all together for the mud designs to climate downpours and dampness. Jharkhand has substantial rainstorm and the mud places of the area are fixed and yet again put after the stormy season. The arrangements start with the improving of the divider surface. Contingent upon the degree of enduring or downpour harm, new dirt is added to cover the breaks or other harmed parts. The whole divider is then scoured to eliminate the previous painting or another layer of earth or cow waste is added over the current divider surface. When this dries, the plan is drawn utilizing a piece of chalk, or recorded into the divider utilizing a sharp item like a nail. Normal earth oxides that will be utilized for painting are ready with water and afterward applied by the plan. The apparatuses and methods utilized for painting differ from one district to another and across networks. 
The distinctions regardless, the last painting produces a smooth surface that attempts to a great extent repulse water or possibly guarantee that it streams down and doesn't infiltrate and debilitate the earthen divider. Along these lines, the act of painting wall paintings becomes vital to the protection of the mud houses.

\section{Origin of Sohrai}

n Hazaribagh area of Jharkhand a native artistic expression is drilled by the ladies. Ceremonial craftsmanship is done on mud dividers to invite the reap and to commend the dairy cattle. The ladies clean their homes and enrich their dividers with paintings of Sohrai expressions. This fine art has proceeded since 10,000-4,000 BC. The name 'Sohrai' is said to have gotten from a paleolithic age word - 'soro', signifying 'to drive with a stick'. Sohrai is a five-day celebration of the Santhal, Munda, Prajapati, Khurmi and Oraon clans in the Indian provinces of Jharkhand, Chhattisgarh, Odisha, and West Bengal. In certain spaces it is abbreviated to three. It is held toward the beginning of the colder time of year collect season. It is praised during Amavasya in Kartik (October-November) month according to the Hindu schedule. In certain locales, it is praised in mid-January. The celebration is like Diwali. Individuals spotless and yet again paint the house. In the evening, they light earthen lights in the dairy cattle sheds and offered penance to the divinity of creatures Pasupati. The celebration is joined by assortment of ceremonies, utilization of handia (rice lager) in bounteous amounts, moving, singing and happy making. The date of the celebration is generally settled by the Manjhi, the town headman in meeting with the older folks of the town. There is no proper date separated, accordingly festivities are regularly stumbled across towns, inside the conventional time period. The object is to empower the townspeople to observe Sohrai in their own towns just as in their family members, particularly wedded sisters and little girls.

Day 1: Rituals and penance of hens are directed by the town cleric in an open space as a conjuring for their divine beings. It is just gone to by men. A similar hen is then cooked and filled in as a blowout with bubbled rice. With this, the manjhi declares beginning of the celebration.

Day 2: The subsequent day is dedicated to conjuring favors from the divine beings for individual homes. The cows are shipped off the fields in the first part of the day to munch. In their nonappearance, the women people of the house brighten the cabins by painting them. In the interim, food is arranged which would fill in as prasad after the puja. After returning, the cows are heartily invited. Their horns are blessed with oil and vermilion. Festoons made by throwing paddy strands are tied across their brows. When the puja gets over, the prasad is dispersed among the townspeople.

Day 3: Amid the boisterous sound of drums, the cows are taken to an open field where they are let free for games and sporting purposes. The ladies additionally join the menfolk this day.

\section{Characteristics of Sohrai \& kohbar Art:}

The canvases at first seem ornamented, while on a more critical watch one can make out that the items portrayed are very straightforward. The Kohvar paintings revere the Devi while the Sohrai wall paintings love the Pashupati or the ruler of creatures. The works of art likewise portray There is additionally a comparability of themes made in the Sohrai and Kohvar artworks and the Isco rock workmanship, Hazaribagh, for example, the portrayal of spotted wheeled creatures during the gather Sohrai canvases. Themes like the Sohrai artistic creations likewise show up on the Indus seals and the painted ceramics of Iran and Mesopotamia. Kamla Baan or a timberland of lotuses and tree of life. The wild creatures portrayed in the works of art are Indian buffalo, bumped cows, tiger, wild pig, nilgai, Indian rhinoceros, and so forth There is a connection between the structures portrayed, as seen between the birds and creatures with their young ones, and among themselves. This relationship is frequently matriarchal in nature, which is roused by the matriarchal part of the general public itself.
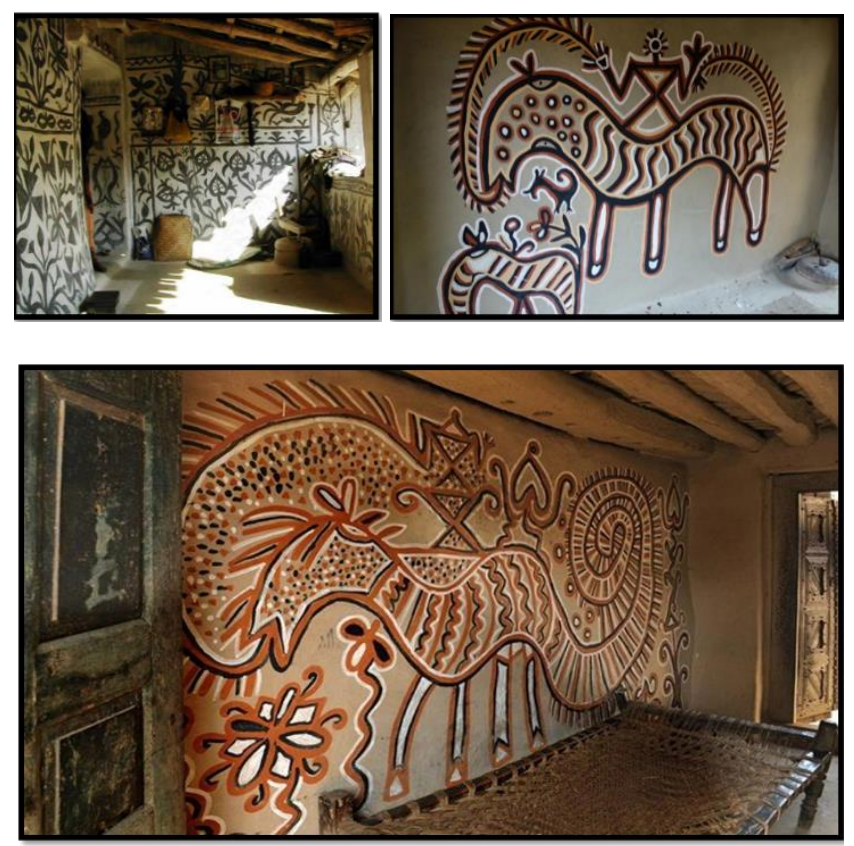

Sohrai \& Kohbar Art

\section{Natural colors \& material}

The Sohrai workmanship, painted on the mud divider, is a practice given over from mother to little girl. It is an emblematic consecrated artistic expression of signs that convey numerous implications. The house is covered with dark earth addressing the belly; the dark earth is covered with the white earth called Dudhi (milk) addressing the god and the images of sperm and light.

At the point when the white is covered completely over the dark earth and cut with a brush, the outcome is viewed as a change of latent earth into a declaration of the mother goddess.

The red line is drawn first as it addresses the 'blood of the precursors', reproduction, and fruitfulness. The following line is dark which connotes everlasting dead stone and sign of the God, Shiva. The following widely inclusive external lines remain in their customary upsides of insurance, constancy, and virtuousness. The white is painted with the last year's rice, grounded with milk into slop. This addresses food.

\section{Process of making}

The wall is first covered with a layer of white mud. While the layer is as yet wet, they draw with their fingertips on it. The cow waste that was before used to cake the dividers of the house is utilized to add tone. It is noticeable because of the recently applied differentiating white mud coat. The 
materials range up to $12 \times 18$ feet. The plans are typically drawn from the craftsman's memory. The individual experience of the craftsman and their connection with nature are the greatest impact. Sohrai ancestral artistic creation is once in a while painted with one tone and in some cases with numerous shadings. However, the tones are all-normal colors. Brown, yellow ochre, red, dark, and other natural tones are utilized to paint. Presently one can see these painted on Government structures and railroad stations as a stage to advance this type of workmanship yet the tones utilized here are engineered. The plans in Sohrai society workmanship range from blossoms and organic products to different other nature-motivated plans. The creatures are very large and unmistakable and the leaves and blossoms fill the remainder of the drawing space. The individual experience of the craftsman and his association with nature is the greatest impact on this workmanship. The examples are straightforward. There is not really any mathematical shape in them and for the most part bends and adjusts which make it look regular. The thick dark layouts rotating with colors make the works of art splendid and excellent. The unmistakable Sohrai workmanship painted on the mud dividers is a matriarchal custom given over from mother to girl. These bright artistic creations are done absolutely by utilizing regular colors blended in mud - Kali Matti, Charak Matti, Dudhi Matti, Lal Matti (Geru), and Pila Matti. Specialists use Datoon (teeth cleaning twig) or material swabs wiped in various earth tones to paint on the dividers - bulls, ponies with riders, wild creatures, trees, lotuses, peacocks, and horned gods. Sohrai works of art are viewed as amazing good fortune canvases.

\section{Conclusion}

Jharkhand's specialties including the Sohrai painting, structure an exceptionally huge piece of the Jharkhand state's social practice in India. The Jharkhand creates show a great deal of abilities. Be that as it may, the craftsmanship quality isn't offset with the essential limited time exercises. Therefore, the Jharkhand creates all in all have not acquired the public and unfamiliar acclaim that it merits. Sohrai artworks, which are strict, common and critical to a lady's reality, are among India's generally sensitive, fragile, imaginative and imperiled native societies. It is the art performed essentially by wedded ladies, after weddings and through gather, and the information and experience are given to more youthful understudies.

Along these, it is important to save and advance the artistic expression. The youthful creators should discover inventive approaches to join the craftsmanship style in their assortments. This would not just give a contemporary wind to the work of art yet in addition help in safeguarding the awesome craftsmanship.

\section{Reference}

1. Bharat Gauri. 'An Enquiry into Santal Wall Painting Practices in Singhbhum, India', Journal of Adivasi and Indigenous Studies 2015;2(1):35-50. Online) at http://joais.org/papers/vol2no1/3.\%20Gauri\%20Bhar at\%2035-50.pdf (viewed on April 2, 2018).

2. Dallapiccola Anna L. ed. Indian Painting: The Lesser Traditions. New Delhi: Niyogi Books, 2011.

3. Huyler, Stephen. Painted Prayers: Women's Art in Village India. London: Thames and Hudson, 1994.
4. Imam, Bulu. 'Kovar and Sohrai Art: The Painted Houses of Hazaribagh' in Heritage India, 2009, 1.4.

5. 'Karanpura must Live: The Story of a Campaign to Save a Landscape" in Sanctuary Asia 37.8. Online at http://www.sanctuaryasia.com/campaigns/10690-

karanpura-must-live-the-story-of-a-campaign-to-save-alandscape.html (viewed on April 2, 2018).

6. Rycroft, Daniel. 'Born from the Soil: The Indigenous Mural Aesthetic of Kheroals in Jharkhand, India', South Asian Studies 1996;12(1):67-81.

7. Troisi, Joseph. Tribal Religion: Religious Belief and Practices Among Santals. New Delhi: Manohar Publications, 1978.

8. http://www.vayavya.in/bulu-imam-v18.html

9. Balasubramanian, Chitra. The beauty of Sohrai and Khovar paintings, 2018. The Hindu. 6 September, https://www.thehindu.com/entertainment/art/thebeauty-of-sohrai-and-

khovarpaintings/article24881453.ece (accessed 29 July 2020).

10. Kandavel, Sangeetha. GI tag for Jharkhand's Sohrai Khovar painting, Telangana's Telia Rumal. The Hindu. 13 May, 2020.

https://www.thehindu.com/entertainment/art/gi-tag-forjharkhandssohrai-khovar-painting-telanganas-teliarumal/article31569123.ece (accessed 1 August 2020)

11. Hoffmann, John: Encyclopaedia Mundarica. In 16 volumes. repr. Delhi, Gian Publishing House, 1990

12. ICKE-SCHWALBE, Lydia: Identity formation in Jharkhand. - Aus: ......Berlin, 2002.

13. Icke-Schwalbe, Lydia: Die Munda und Oraon in Chota Nagpur. Berlin, 1980.

14. Roy SC. The Mundas and their country. Ranchi 1912, repr. Delhi, 1974. 